\title{
Inequalities in LPG and electricity consumption in India: The role of caste, tribe, and religion
}

\begin{abstract}
This paper examines the role of caste, tribe, and religion in determining energy inequality in India. We provide evidence by using the National Sample Survey Organisation data from the 68th round (2011-12) of 87,753 households. We estimate the inequalities in access to Liquid Petroleum Gas (LPG) and electricity usage by the households belonging to the three major disadvantaged groups in India, viz., the scheduled castes, the scheduled tribes, and the Muslims. The results of our empirical analysis suggest that, after controlling for the determinants which impinge on the households' microeconomic demand and regional supply characteristics, the households belonging to the scheduled tribe and scheduled caste communities do have significantly poorer access to LPG and electricity usage as compared to the upper caste households. The decomposition analysis of average differences in the predicted outcomes shows that it is the scheduled caste and scheduled tribe households who would appear to face most discrimination. The Muslim households too face significant inequality in accessing LPG. Policy implications of the findings are considered.
\end{abstract}

Key words: cooking fuel; electricity; inequality; discrimination 


\section{Introduction}

The importance of access to modern energy and equality in achieving sustainable economic development in low income countries is widely recognised (Ahn and Graczyk, 2012; Bhattacharyya, 2006; IEA, 2002; WEC, 2001; World Bank, 2003). Apart from its many direct benefits, the access to modern energy has many indirect but positive effects in many other dimensions as well: contributing to improvements in health, development of microenterprises, improvements of environmental quality and so forth (Pachauri and Spreng, 2011). However, estimates suggest that approximately 1.3 billion people in the developing countries do not have access to electricity and more than 2.5 billion lack access to safe cooking fuels (Chaurey et al., 2004; WEO, 2014).

Although there has been substantial progress in the number of households accessing modern energy services in India since independence, the country still contains the largest number of energy deprived people in the world. The total population of India is approximately one fifth of the world's total, but the energy consumption of India is approximately only 4 per cent of the world's total (Raha et al., 2014). Due to increasing international focus and recent awareness of policy makers in India, few policy initiatives started to help the households belonging to the disadvantaged social groups to access modern energy goods. ${ }^{1}$ However, like other normal goods, the idea that energy goods can suffer from inequality and discrimination has not received due attention in the literature.

The purpose of this paper is to examine the inequalities and discrimination in accessing clean cooking fuels and electricity by households in India in a multivariate framework. We investigate, in particular, the inequality in access to Liquid Petroleum Gas (LPG) and electricity by three major disadvantaged groups in the country, viz., the scheduled castes (SCs), the scheduled tribes (STs), and the Muslims. The results of our analysis suggest that, after controlling for the other socioeconomic factors which impinge on the households' demand and supply characteristics (Danh and Khai, 2015; Magri, 2007), the households belonging to these disadvantaged groups do have significantly poorer access to LPG and electricity usage

\footnotetext{
${ }^{1}$ For example, the Rajiv Gandhi Grameen Vidyutikaran Yojana (RGGVY) for electricity, Scheduled Castes Sub Plan (Government of Punjab) for cooking gas and electricity, Deen Dayal Upadhyaya Grama Jyoti Yojana (DDUGJY) for electricity, Integrated Power Development Scheme for electricity, and LPG Agency for Scheduled Castes for cooking gas, among others.
} 
as compared to the upper caste households (which is our comparison category; this category consists of all the non-scheduled caste Hindu households plus the households belonging to the numerically small religious groups in the country, such as the Sikhs, Jains, and Buddhists ${ }^{2}$ ). We also present evidence of unequal treatment - induced by the physical and social isolation as well as outright discrimination against them - which significantly determines a portion of total inequality in access to these energy goods by the three disadvantaged groups.

The plan of the rest of the paper is as follows. Section 2 presents energy issues, social structure, and related literature. Section 3 presents econometric specification and the description of the dataset and variables employed. Section 4 discusses the issues of parameter identification and presents the results of the multivariate regression and decomposition analysis. Section 5 concludes with the policy implications.

\section{Energy issues and social structure in India}

\subsection{Energy issues in India}

In contrast to the developed countries where air pollution is generally regarded as an urban problem, in the developing countries, the indoor air pollution is probably of greater consequence for the health and well-being of the population. The primary reason for the indoor air pollution is the type of cooking fuels used by the households. The biomass fuels and coal - both of which are widely used - are not only relatively inefficient in energy production, they also emit high levels of carbon-dioxide (CO2) and other hazardous substances, contributing to the respiratory problems, cancer, blindness, and other illness (Ellegard, 1996; Ellegard and Egneus, 1993; Mishra et al., 1999; Smith, 1994, 1993; Zhang and Smith, 2007). These necessitate increased medical expenditures and time-off work for the household and erode their labour productivity.

\footnotetext{
${ }^{2}$ In other words, we are referring to all households other than the scheduled castes, scheduled tribes, and Muslim households as 'upper caste households'. As a purely literal description, this is of course, not entirely correct, for this category would include Christians and members of the other backward castes (OBCs) who will not consider themselves as upper caste. Our categories, like most used in social sciences, are not isomorphic. We recognise that those within particular categories do not wholly or uniformly share the ideal-typical or nonquantified characteristics attributed to each. We rely on tendencies and prevalences, not isomorphic uniformities.
} 
In India, the only widely used clean cooking fuel available is the Liquefied Petroleum Gas (LPG) in cylinders (Bhattacharyya, 2006). ${ }^{3}$ These are heavily subsidised by the government when targeting the poorer households. However, the gas distribution agencies are usually owned by members of the high income social groups and they often prioritise the distribution of LPG cylinders to suit their own economic interests. Therefore, the subsidies generally benefit the households with higher social status.

Although the access to LPG has increased in the last decade in India, the progress has been very slow. According to the Census of 2011, less than 30 per cent of the households have access to clean cooking fuels. While 66 per cent of the urban households have access to the clean cooking fuel, the figure for the rural households is only 12 per cent (Census of India, 2011; D'Sa and Murthy, 2004). Apart from the supply side issues, the targeted groups may also, of course, have a lack of demand for LPG due to the cost of cooking equipment, bureaucratic difficulties in getting an official LPG account, or even that the subsidised LPG cylinders may be too costly for many in the marginalised social groups. ${ }^{4}$ Various governments in the last few years have adopted a number of programmes for the marginalised and poorer households (such as the Rajiv Gandhi Gramin LPG Vitaran Yojana and Pratyaksh Hastantrit Labh (PAHAL)). However, the widespread corruption in the form of fake customers, duplicate connections, lack of banking facilities, and black marketing of LPG have considerably reduced the impact of these programmes.

While the legal usage of LPG at the household level is limited to cooking, the use of electricity is, of course, much more widespread. Indeed, it is possible to argue that the access to electricity is probably of greater consequence than the access to LPG for improving the

\footnotetext{
${ }^{3}$ And although a handful of blocks in the urban areas are now equipped with piped gas, they are miniscule in numbers. Similarly, less than 1 per cent of the households in India use electricity or biogas for cooking. The household level data on energy consumption in India were first collected by the National Council of Applied Economic Research in the early 1960s. These data were employed for the first time in an Energy Survey of India report in 1965. Since then a number of other studies and reports have examined the patterns of energy usage in India. See Pandey (2002) for a review. Our focus, as we have stated, is on the energy consumption by the three marginalised social groups in the country.

${ }^{4}$ There is also the issue here that many of the households having home based enterprises may prioritise the use of LPG illegally for commercial purposes rather than for domestic cooking. This clearly has a gender dimension in that the cooking is mostly done by women in the households who are then forced to use hazardous biomass fuels and/or coal with detrimental consequences for their health. This is an important side effect of having home based enterprises particularly in poor communities, and does not seem to have received much attention in the literature. Analysis morbidity and mortality by gender in households with home based enterprises would clearly appear to be an interesting area of future research.
} 
economic outcomes. However, while the official estimates indicate that more than 90 per cent of the rural areas and 100 per cent of the urban areas were electrified in the decade of 2000-2010, the uninterrupted delivery of electricity is often not achieved (Alam et al., 1998). It is not uncommon for many villages and urban areas to be supplied with electricity for only a few hours a day. Public sector entities dominate the energy sector in India and subsidies given are often untargeted. Both the states and national governments in their pronouncements have regularly emphasized that the provision of access to electricity for disadvantaged sections of the population is of utmost importance. However, because the village electrification's primary objective was to increase the farm output until early 2000 , the question of the actual provision of electricity to households was neglected. Since 2004, under the Rajiv Gandhi Vidyutikaran Yojna, the policy shifted its focus from the grid coverage in the village to the household level electrification in the rural areas. Bhattacharyya (2006) mentions that electricity theft and leakages are widespread in many areas of the country. And, because, the primary objective of the rural electrification had been irrigation, it is the richer farmers and large land owners who have benefited the most from the subsidised supply of electricity. In the urban areas too, it is claimed that the supply of electricity is least interrupted in those areas where the members of the high income social groups generally live.

\subsection{Social structure in India}

The scheduled caste is the term applied to a wide range of Hindu groups belonging to the lowest rung in the caste hierarchy. They comprise about 16 per cent of India's population and they continue to face many disadvantages, even though discrimination on the basis of caste has been declared illegal in the Indian constitution. The scheduled tribes include most socalled tribal or indigenous communities throughout India. Considered to be outside the Hindu caste system, they comprise about 8 per cent of India's population. Both the scheduled castes and scheduled tribes are widely viewed as being at the lowest level of the social scale. Muslims in India, who comprise about 14 per cent of India's population, are also considered to be considerably deprived in many dimensions. ${ }^{5}$

\footnotetext{
${ }^{5}$ See Sachar Committee Report (2005). See also Desai and Kulkarni (2008) and Asadullah and Yalonetzky (2012).
} 
So far as the three marginalised groups are concerned, their places of residence would appear to pose a particular problem in their accessing and consuming of both LPG and electricity. On average, these households are socioeconomically backward compared to the upper caste households and they mostly reside in the poorer neighbourhoods or slums in the urban areas. In the rural areas, the scheduled caste households are often segregated in hamlets outside the main perimeters of the villages and this makes it possible to discriminate against them by the suppliers of the energy goods. Members of the scheduled tribe communities often live in the relatively remote areas. And while the Muslim communities mostly live in the urban areas, they live within the city boundaries in Muslim ghettos (Gayer and Jaffrelot, 2012), where households are not always properly accounted for by the official authorities. There are also cases of illegal access to electricity due to lack of law enforcement in many urban slums, where single direct-line connection is shared by many households. These then lead to the loss to the electricity utilities, which in turn may then lead to a reduction in the supply of electricity to these socioeconomically backward urban blocks.

Most studies of energy access in developing countries can be classified, as Kanagawa and Nakata (2008) have noted, into three broad types: descriptive, experimental, and analytical. Kanagawa and Nakata (2008) also noted that while the descriptive and experimental studies are quite common in the literature, the analytical studies are less so. In the Indian context, while a few studies have looked at the determinants of access to electricity in such a framework (Kemmler, 2007; Oda and Tsujita, 2011), even fewer have looked at the socioeconomic determinants of access to clean cooking fuels and electricity consumption in such a framework (Gupta and Köhlin, 2006; Rao and Reddy, 2007). Further, while a few researchers have examined the impact of the scheduled caste and scheduled tribes status in the context of accessing electricity, the impact of the Muslim status in accessing electricity and LPG has received very little attention (see, however, (Oda and Tsujita, 2011; Thorat, 2009)). In our work, we shall analyse the socioeconomic determinants of access to clean cooking fuels and electricity consumption by households in India, with main focus being on these determinants as they relate to various social groupings in the country.

Of the very few analytical studies referred to above, Kemmler's (2007) is probably the most relevant in the context of discussions in the present paper. Kemmler's study suggested that the scheduled caste and scheduled tribe households face discrimination in accessing 
electricity; however, the study did not present any quantitative analysis for this conclusion (besides excluding the urban areas from its analysis). Kemmler's study also excluded Muslim households from its analysis and was limited to electricity access only. Our analysis differs in including all three marginalised social groups and considering both access to LPG and electricity consumption (in both the rural and urban areas).

In developed countries access to any particular type of energy good and its consumption level are mainly demand driven at the household level. In a developing country such as India, however, the supply side factors are also of great importance. And it is not only the conventional types of supply side factors ((such as whether the household is located in the rural or urban areas (with the households in the rural areas being more prone to suffer relatively poor supplies) and the state-level heterogeneity in energy infrastructure and prices)) that are important in India, but also what one might call the hidden or not-so transparent supply side factors such as overt or latent discrimination against particular social groups in the supply of energy goods. In other words, the impacts of education, household income, age or other determinants of access to modern energy goods may be unfavourably skewed against the marginalised social groups.

\section{Econometric specification, Data, and Variables}

\subsection{Econometric specification}

As access to electricity is now considered almost universal in India, the dependent variable in the case of electricity is the natural log of total electricity consumption by a household (Meier and Rehdanz, 2010), while, in the case of access to LPG, it is binary (Cameron and Trivedi, 2010; Hendrickx, 2002; Long and Freese, 2001). Further, since we hypothesise that a household's total consumption of electricity and probability of access to LPG depend on the social groupings, even after controlling for the other economic characteristics (Heltberg, 2004; Kemmler, 2007; World Bank, 2003), we linearly specify $Y_{i}^{*}$ for both the energy goods in equation $(A)$. 
$Y_{i}^{*}=\beta+\sum_{m=1}^{q} \Omega_{m} X_{i m}+\sum_{j=1}^{k} \alpha_{j} X_{i j}+\varepsilon_{i}$

and

$Y_{i}=\left\{\begin{array}{l}1 \text { if } Y_{i}^{*}>0 \\ 0 \text { otherwise }\end{array}\right.$

Considering that the Generalised Linear Model in equation $(A)$ is consistent for both the continuous (observable) and binary (unobservable) dependent variables (Liao, 1994), for the access to $L P G$, equation $(B)$ is the measurement equation that connects the latent dependent variable in equation (A). In equation (B) the variable takes value 1 if the household has access to LPG, zero otherwise. Thus, the link function of $Y_{i}^{*}$ in equation $(A)$ is unity for the log of electricity usage and it changes to probit for the access to LPG. ${ }^{6} \sum_{m=1}^{q} \Omega_{m} X_{i m}$ is the sum of dummy variables representing the scheduled caste, scheduled tribe and Muslim households and $\sum_{j=1}^{k} \alpha_{j} X_{i j}$ is the set of other control variables in the specification. Therefore, $\beta+$ $\sum_{j=1}^{k} \alpha_{j}$ can be defined as the coefficients for the upper caste households. The specification of dependent variable and covariates in the equations above are discussed below. For the identification of the vector of coefficients we assume that the covariance between errors $\varepsilon_{i}$ and covariates $X_{i}$ is zero.

\subsection{Data and Variables}

The data used in the analysis come from the National Sample Survey Organisation (NSSO). The NSSO conducts different types of surveys in its different rounds, and each round consists of a year's duration. The household consumer expenditure survey (CES) is the main component of the organisation and it takes place every five years. The data collected within the period of 2011 - 2012 focuses on the "Employment and Unemployment" and "Household Consumer Expenditure". The Household Consumer Expenditure Survey is termed as Type 1 data of $68^{\text {th }}$ round of NSSO and it is the ninth and latest survey in the CES series (Kumar et al., 2012).

\footnotetext{
${ }^{6}$ Here the probit model can be expressed in terms of probability for a binary outcome variable, $\operatorname{Prob}(y=1)=$ $1-F(-())=.F()=.\Phi($.$) , where the general form of the CDF of error term is replaced by the standard$ normal CDF, $\Phi$. Therefore, for the nonevent $\operatorname{Prob}(y=0)=1-\Phi($. $)$. The argument of the function $F,($.$) , from$ equation $\mathrm{A}$ is $\beta+\sum_{m=1}^{q} \Omega_{m} X_{i m}+\sum_{j=1}^{k} \alpha_{j} X_{i j}$.
} 
The primary objective of the NSSO CES 68th round Type 1 is to collect information about the patterns of household level monthly per capita expenditure (MPCE) for both the rural and urban areas. The survey covers all the possible regions of India and also provides information of the social groupings of the households: Scheduled Caste, Scheduled Tribes, and Muslims.

Our sample includes 87753 households from all the states and union territories of India. ${ }^{7}$ The description of the variables used are as follows:

\subsubsection{Dependent Variables}

LPG access. The first dependent variable is the access to LPG by a household. The sample provides nine categories of primary source of cooking fuel. Of these, LPG and electricity are considered as clean cooking fuels and the rest (such as coal, kerosene, firewood and chips, dung cake etc.) as hazardous. Although the safety standards of kerosene are marginally better than the other natural biomass fuels, its harmful effects have been widely acknowledged in the literature (Fullerton et al., 2008; Golshan et al., 2002; Lam et al., 2012). Some recent reports also indicate that households mostly use kerosene for purposes other than cooking (Government of India, 2012)..$^{8}$ Therefore, in our analysis we take LPG as the only clean cooking fuel available to the households in India. Although access to electricity has considerably increased, access to LPG has shown negligible growth in the last few decades. In our sample, approximately 48 per cent of the households have reported access to LPG. There are large differences among the rural and urban households: whilst more than 70 per cent of the households have access to LPG in the urban area, less than 30 per cent of the households have access to LPG in the rural areas.

Table 1 suggests that almost 55 per cent of the upper caste households have access to LPG. Among the three disadvantaged groups, 45 per cent of the Muslim households, 39 percent of the scheduled tribe and 34 per cent of the scheduled caste households, respectively, have access to LPG. Thus, without controlling for the determinants of access to LPG, the Muslim

\footnotetext{
${ }^{7}$ Union territories are relatively small administrative units which are mostly governed by the President of India through his/her representatives.

${ }^{8}$ There is, of course, here the question about the choices people make. In the utilitarian framework, an unconstrained household chooses the best available option. In our empirical analysis, we control for the households' socioeconomic characteristics constraining their choices, with LPG remaining as the only available option. Similar reasoning applies in the case of electricity consumption.
} 
households have significantly better access to LPG than the Scheduled Tribe and Scheduled Caste households in this sample. However, the upper caste households, as a social group, have the best access to LPG in this sample.

Table 1: Distribution of LPG and Electricity by Social Groups.

\begin{tabular}{lcc}
\hline & $\begin{array}{c}\text { LPG (per } \\
\text { cent access) }\end{array}$ & $\begin{array}{c}\text { Average Electricity consumption } \\
\text { (in KWh) }\end{array}$ \\
\hline Upper Caste Hindu Households (Others) & 0.545 & 95.212 \\
& $(0.497)$ & $(96.158)$ \\
Scheduled Tribes Households & 0.388 & 64.090 \\
& $(0.488)$ & $(55.218)$ \\
Scheduled Caste Households & 0.337 & 72.715 \\
& $(0.472)$ & $(63.622)$ \\
Muslim Households & 0.453 & 89.140 \\
& $(0.497)$ & $(92.010)$ \\
\hline Total Sample Size & 87753 & 87753 \\
\hline mean coefficients; sd in parentheses & &
\end{tabular}

Electricity. The second dependent variable is the amount of electricity consumption by a household in the last thirty days in the sample. It is measured in the standard units of KWh. In India, electricity is primarily used for lighting in substitutions of biomass and other hazardous fuels for lighting (Khandker, Shahidur R.; Barnes, Douglas F.; Samad, 2010; Modi, 2005). In the NSSO survey primary source of lighting is divided into six categories. However, considering the recent reports on high electricity accessibility at the household level, we employ last 30 days' electricity consumption of the households as the relevant variables instead of accessibility. In our sample, regarding accessibility, more than 98 percent households have access to electricity. The average electricity consumption is around $88 \mathrm{KWh}$ in the sample. The average electricity consumption in the urban area is around $110 \mathrm{KWh}$ and that in the rural area $68 \mathrm{KWh}$.

Table 1 describes the average electricity consumption by social groups. Similar to the data presented for the access to LPG in Table 1, the upper caste households consume, on average, most electricity in the sample. Although all the three marginalised groups have consumption less than the upper caste households, the average electricity consumption of the Muslim households, again, is significantly higher than the Scheduled Tribe and Scheduled caste households. 


\subsubsection{Explanatory Variables}

In line with our previous discussion, the explanatory variables included in the analysis are designed to capture the influences of both the demand and supply side factors. The variables are as follows:

Social Groups. Although the NSSO classifies sample into several groups of SC, ST, and all other religions, we categorise the sample into four categories. Scheduled caste is the binary variable representing the scheduled caste households and scheduled tribe is the binary variable representing scheduled tribe households. Muslim is the dummy variable representing Muslim households in the sample. All other categories of the households are the base category for the comparisons in the estimation and is referred to in this paper as the upper caste households. Proportion of the upper caste, scheduled tribes, scheduled caste, and Muslim households is approximately sixty one, twelve, fourteen, and thirteen per cent, respectively, in our sample. These social categories determine the inequality in accessing LPG and electricity at the household level. However, we also assume that the demand side factors, in terms of the socio-cultural heterogeneity in consumption and choice patterns of different groups, are also captured by these variables.

Education. We use the level of education of the head of the household. Although the information is provided for all the household members, we assume that the education level of the head of the household is an indicator of the overall level of education of the household. In the sample, the education levels of the household's head are divided into thirteen categories: from illiterate to postgraduate and above. However, for the multivariate analysis in this paper, we constructed three levels of education. Households where the head is reported to have no formal education or illiterate are considered in the lowest category of the education levels. Formal schooling up to the primary level is taken to belong to the second category of the education level, while the households where the head has attained higher secondary, diploma, or college level education are considered to belong to the category of the high education. We assume that educated households' demand, through various structural mechanisms, more of LPG as a clean cooking fuel and consume more electricity. 
Consumption Expenditure. It is now widely accepted that in developing countries (and even in the developed countries to an extent), the households' living standards are better measured by their consumption expenditure than by income (Blundell and Preston, 1995; Jones et al., 2010; Meyer and Sullivan, 2011, 2008, 2003; Poterba, 1989; Slesnick, 1993). Our dataset contains information about household consumption expenditure and the full information on households' consumption is then used in the analysis as a continuous variable. We assume that the households with higher per capita consumption expenditure will, ceteris paribus, use more of LPG and consume more of electricity.

The NSSO sample uses two methods for comparing living standards across households: the uniform reference period (URP) and the mixed reference period (MRP) methods, respectively. The URP method records the main expenditure on all the items consumed during the last 30 days. In the MRP method the consumption expenditure is recorded for 365 days for some items (mainly clothing, bedding, footwear etc.) and for 30 days for other items (mainly food, intoxicants, and perishable goods) (Government of India, 2012; Kumar et al., 2012). To capture the detailed information of the households' living standards, we use the data provided by the MRP method in our analysis. The monthly per capita expenditure (MPCE) is the household's consumption expenditure over the period divided by the household's size. The MPCE is recorded in Indian Rupees. We assume that the higher the MPCE, the higher will be the consumption of electricity and access to LPG.

Location. The location of the household is represented by two different types of variables, first by rural urban classification and second by the state/union territory in which the household is located. These variables, we have assumed, determine the supply of energy goods and state level price and cross-price differentials in the model. The first categorisation is on the basis of rural-urban classification. As the households in India, conditional on their rural location and inclusion of other determinants, receive less supply of LPG and electricity, the access to LPG and consumption levels of electricity should be determined by this factor. Similarly, as all the states and union territories in India have heterogeneous infrastructure in supplying LPG and electricity, and separate pricing policies for these, we include dummies for all the states and union territories in our analysis. 
Additional Explanatory Variables. In addition to the variables above, we have also included the following explanatory variables: ration card, household's main occupation, average age of the household, size of the household, household's ownership of the dwelling, and 'ceremony' within the last 30 days. Justification for including these variables is as follows. We assume that the households who possess ration cards are better equipped with documents and have relatively more knowledge to access LPG and demand electricity supply. In our sample, around 80 per cent of the households possess ration card. The reason for including the size of the household is to simply control for the amount of electricity consumption in a larger household. However, in India knowing the right persons and those who can be persuaded to intercede on one's behalf (i.e. having the right contacts) can often be important in accessing a number of different public services. A large-sized household, with a larger number of members, other things being equal, will have more 'contacts' than smaller-sized households. We therefore expect the larger sized households to have significantly more chances of accessing LPG.

Household's main occupation is classified into two categories: agriculture and nonagriculture. In our sample, a quarter of the households engaged in agricultural activities are in the very poor category, while less than 10 per cent of these households are in the not poor category. We hypothesise that the agricultural households have less chances of accessing LPG and will consume less electricity.

In India, there are round the year cultural festivities for one reason or another and it is possible that the data may include the measurement error of consumption shock resulting from these events. Therefore, we include the variable 'ceremony' in our analysis to control for any special occasion in the household in the last 30 days. It is clear from the instructions to the field staff that the main purpose of the ceremony variable was to account for the consumption shock that results from a large number of meals (not just snacks) being served to non-households members on these occasions. ${ }^{9}$ Another variable in the specification is whether the household owns the dwelling where it resides. We assume that the households who own dwellings have higher chances to remain in the same dwelling and invest more in durable goods which require LPG and electricity.

\footnotetext{
${ }^{9}$ Instructions to the field staff, Chapter 3, Volume 1, Page C-14.
} 


\subsubsection{Distribution of LPG and Electricity}

Having discussed the dependent and explanatory variables, it may be useful, before proceeding to specification and estimations, to present a brief description of the distribution of LPG and electricity by the household characteristics.

Table 2: Key Variables and Sample Means

\begin{tabular}{|c|c|c|}
\hline 1 & $\begin{array}{c}\text { LPG (per } \\
\text { cent access) }\end{array}$ & $\begin{array}{c}\text { Average Electricity consumption } \\
\text { (in } \mathrm{KWh} \text { ) }\end{array}$ \\
\hline Informal or no education & $\begin{array}{c}0.230 \\
(0.420)\end{array}$ & $\begin{array}{c}65.368 \\
(61.835)\end{array}$ \\
\hline Formal school education & $\begin{array}{l}0.450 \\
(0.497)\end{array}$ & $\begin{array}{l}80.880 \\
(73.645)\end{array}$ \\
\hline Higher education (college) & $\begin{array}{c}0.766 \\
(0.423)\end{array}$ & $\begin{array}{c}119.415 \\
(120.392)\end{array}$ \\
\hline Agriculture household & $\begin{array}{c}0.209 \\
(0.407)\end{array}$ & $\begin{array}{c}66.900 \\
(60.835)\end{array}$ \\
\hline Non-agricultural household & $\begin{array}{c}0.552 \\
(0.497)\end{array}$ & $\begin{array}{l}92.485 \\
(93.050)\end{array}$ \\
\hline Ration card & $\begin{array}{c}0.474 \\
(0.499)\end{array}$ & $\begin{array}{c}89.554 \\
(88.043)\end{array}$ \\
\hline No ration card & $\begin{array}{c}0.531 \\
(0.499)\end{array}$ & $\begin{array}{c}79.278 \\
(88.683)\end{array}$ \\
\hline Ceremony in the household (30 days) & $\begin{array}{c}0.558 \\
(0.496)\end{array}$ & $\begin{array}{c}108.545 \\
(114.278)\end{array}$ \\
\hline No ceremony ( 30 days) & $\begin{array}{c}0.484 \\
(0.499)\end{array}$ & $\begin{array}{l}87.110 \\
(87.698)\end{array}$ \\
\hline Household owns the dwelling & $\begin{array}{c}0.451 \\
(0.497)\end{array}$ & $\begin{array}{c}88.379 \\
(89.627)\end{array}$ \\
\hline Household does not own the dwelling & $\begin{array}{c}0.644 \\
(0.478)\end{array}$ & $\begin{array}{c}83.287 \\
(80.277)\end{array}$ \\
\hline Total Sample Size & 87753 & 87753 \\
\hline
\end{tabular}

As would be expected, there exists significant differences by education levels in the sample. Only 23 percent of the households have access to LPG where head of the household is informally educated or has no formal education. This proportion rises to 45 per cent for the households with formally educated head up to secondary education and around 77 per cent for the household were the head has a college degree or higher qualification. Similarly, for three categories of education the average electricity usage increases from $65 \mathrm{KWh}$, to 81 $\mathrm{KWH}$, to $119 \mathrm{KWh}$, respectively. Therefore, in our sample, educated households have higher proportion of access to LPG and higher electricity usage. 
Only 21 percent of the agricultural households have access to LPG compared to 55 percent of the non-agricultural households. Similarly, while the average electricity usage among the agricultural households is around $67 \mathrm{KWh}$, it is more than $92 \mathrm{KWh}$ for the non-agricultural households. Households without ration cards have less electricity usage in comparison to the households with ration cards, though access to LPG is marginally better for the households without the ration cards (when we do not control for the other factors).

Households which had 'ceremony' in the last 30 days in the sample record more access to LPG and higher usage of electricity. Although the difference is marginal in the case of LPG, it is significantly higher in the case of electricity consumption. Household with the ceremony have average consumption of $109 \mathrm{KWh}$ of total electricity, whereas without ceremony the average total electricity consumption is $87 \mathrm{KWh}$ in the sample. As mentioned above, this variable is useful in controlling for the consumption shock of a household which had conducted a ceremony in the last 30 days. Without controlling for the other factors, 45 percent of the households who own the dwelling have access to LPG and have average electricity usage of $88 \mathrm{KWh}$.

\section{Identification Issues and Estimation Results}

\subsection{Identification issues}

While a higher standard of living - measured in our case by a higher level of consumption expenditure - can lead to an increased usage of modern energy goods, increased usage of modern energy goods can also, of course, contribute to a higher level of income and standard of living. A household's income, ceteris paribus, would depend on the health of its members (healthy members being more productive than the unhealthy members), and the health of its members would clearly be influenced by the extent to which it has access to non-hazardous modern energy goods (Behm, 1980; Benzeval et al., 2000; Deaton, 1999). III health may also, of course, deplete family savings or lead to family indebtedness through illness related expenditure. ${ }^{10}$ To remove the simultaneity bias requires instruments for consumption expenditure - exogenous variables that are correlated with consumption expenditure but are not otherwise associated with energy goods usage. In our case the variables land holdings

\footnotetext{
${ }^{10}$ In this context, see also (Rao, 2013).
} 
and the possession of a car/jeep are seen to satisfy the requirements for use as instrumental variables. These variables are correlated with consumption expenditure but are not directly associated with the use of electricity or LPG access. Larger landholdings and use of cars and jeeps are generally associated with higher income and hence consumption in India (Besley and Burgess, 2000), while there are no strong reasons to believe that electricity or LPG usage lead to higher landholdings or ownership of cars. They can therefore be used as instruments for consumption expenditure, and consistent estimation can be obtained by using instrumental variable (IV) estimation method. ${ }^{11,12}$ In IV estimation, we use two stage least squares (2SLS) and Maximum Likelihood (IV-probit) Estimation (MLE) techniques for continuous and binary dependent variables, respectively.

\subsection{Estimation Results}

\subsubsection{Electricity Consumption}

We first consider the determinants of electricity consumption. The results are presented in Table 3. Our main results pertain to IV estimates (column 2), though we also report the results of the OLS estimates (column 1).

Among the social group variables, the coefficients of the scheduled tribe and scheduled caste variables are negative and significant in both regressions. The coefficient of the Muslim variable is also negative and significant in the OLS estimate, but insignificant in the IV-2SLS estimates. For both the scheduled caste and scheduled tribe households, the size of the

\footnotetext{
${ }^{11}$ Both the Durbin-Wu-Hausman test and Wald test reject the null hypothesis of exogenity of consumption expenditure for 2SLS and IV-probit (Davidson, 2000). For the relevance of instruments, we tested the partial correlation in the first stage regression of $2 \mathrm{SLS}$. Also, for $2 \mathrm{SLS}$, we tested the joint significance of our instruments in the first stage and following (Stock et al., 2002) we find strong evidence of correlation. In the case of IV-probit we extracted the first stage estimates of MLE and found strong partial correlation of our instruments with the endogenous regressor.

For the validity of instruments, we used Sargen's test of overidentification (Sargan, 1958) for 2SLS, and found strong evidence that our instruments are valid. For IV-probit, as we prefer MLE over two step procedure (David A. Freedman and Jasjeet S. Sekhon, 2010; Heckman, 1979; Newey, 1987), we faced a minor limitation of testing the validity of instruments in the nonlinear case. However, we use 2SLS only for this test. Again, the Sargan's test did not reject the null and we conclude that our instruments are valid.

${ }^{12}$ There is also a minor issue here in that the NSSO consumption expenditure data include expenditure on energy goods (both traditional and modern). The expenditure on these items as a proportion of the total household consumption expenditure, however, is microscopically small. Nevertheless, as a robustness check for the analysis presented in the paper (based on the full NSSO expenditure data), we also carried out an analysis excluding expenditure on energy goods from the NSSO consumption expenditure data. The results remain unchanged and can be easily replicated.
} 
coefficient is smaller after correcting for the endogeneity. The scheduled tribe status leads to about 10 percent and schedule caste status about 5.6 percent less electricity usage compared to the upper caste households.

Table 3. Electricity consumption: Results of the regression analysis.

\begin{tabular}{|c|c|c|}
\hline Variable & $\begin{array}{c}\text { Natural Log of electricity } \\
\text { usage (OLS) (1) }\end{array}$ & $\begin{array}{c}\text { Natural Log of the electricity } \\
\text { usage (IV-2SLS) (2) }\end{array}$ \\
\hline Scheduled Tribe Households & $\begin{array}{l}-0.132^{* * *} \\
(-16.76)\end{array}$ & $\begin{array}{l}-0.104^{* * *} \\
(-12.91)\end{array}$ \\
\hline Scheduled Caste Households & $\begin{array}{l}-0.104^{\star \star \star} \\
(-17.60)\end{array}$ & $\begin{array}{c}-0.0560^{* * *} \\
(-8.81)\end{array}$ \\
\hline Muslim Households & $\begin{array}{c}-0.0130^{* *} \\
(-1.98)\end{array}$ & $\begin{array}{c}0.00569 \\
(0.83)\end{array}$ \\
\hline Per Capita Consumption Expenditure (MPCE) & $\begin{array}{c}0.000000977^{* * *} \\
(34.55)\end{array}$ & $\begin{array}{c}0.00000244^{\star \star \star} \\
(41.65)\end{array}$ \\
\hline Ceremony in the Last 30 Days & $\begin{array}{c}-0.00692 \\
(-0.43)\end{array}$ & $\begin{array}{c}-0.210^{\star * *} \\
(-8.12)\end{array}$ \\
\hline Ration Card & $\begin{array}{c}0.0993^{* \star \star} \\
(16.98)\end{array}$ & $\begin{array}{l}0.132^{\star \star \star} \\
(20.33)\end{array}$ \\
\hline Household's Main Occupation is Agriculture & $\begin{array}{c}-0.0449^{* * \star} \\
(-8.55)\end{array}$ & $\begin{array}{c}-0.0629^{* * \star} \\
(-11.08)\end{array}$ \\
\hline Illiterate or informally Educated & $\begin{array}{l}-0.387^{\star \star \star} \\
(-54.04)\end{array}$ & $\begin{array}{l}-0.168^{\star \star \star} \\
(-16.54)\end{array}$ \\
\hline Formal Schooling up to Primary Level & $\begin{array}{l}-0.225^{* * *} \\
(-39.38)\end{array}$ & $\begin{array}{c}-0.0583^{* * *} \\
(-7.12)\end{array}$ \\
\hline Average Age of the Household & $\begin{array}{c}0.0272^{* * *} \\
(35.10)\end{array}$ & $\begin{array}{c}0.0192^{* * *} \\
(21.58)\end{array}$ \\
\hline Square of the Average Age of Household & $\begin{array}{c}-0.000301^{\star \star *} \\
(-30.58)\end{array}$ & $\begin{array}{c}-0.000240^{* * \star} \\
(-20.95)\end{array}$ \\
\hline Total Size of the Household & $\begin{array}{l}0.101^{* * *} \\
(81.64)\end{array}$ & $\begin{array}{l}0.122^{* \star *} \\
(78.64)\end{array}$ \\
\hline Household Owns the Dwelling & $\begin{array}{l}0.259^{* \star *} \\
(40.04)\end{array}$ & $\begin{array}{l}0.319^{\star \star \star} \\
(42.69)\end{array}$ \\
\hline Household in the rural area & $\begin{array}{l}-0.329^{* \star *} \\
(-68.09)\end{array}$ & $\begin{array}{l}-0.263^{* \star *} \\
(-45.65)\end{array}$ \\
\hline Constant & $\begin{array}{c}3.416^{* * *} \\
(160.31)\end{array}$ & $\begin{array}{l}2.904^{\star \star \star} \\
(98.87)\end{array}$ \\
\hline Observations & 87753 & 87753 \\
\hline$R^{2}$ & 0.43 & 0.31 \\
\hline
\end{tabular}

The coefficient of the monthly per capita expenditure is positive and significant in both regressions. In the 2SLS estimation, the size of the coefficient is more than twice as large as in the OLS estimation. Of the other variables, both the low education households' have negative and significant coefficients in both columns. The 2SLS estimates show that the 
households with illiterate or informally educated heads use around 10 percent less electricity after controlling for other factors.

The coefficient of the household in the rural area is negative in both regression, the size of the coefficient in column 3 showing that the rural households use almost 26 per cent less electricity than urban households. The coefficient of the 'ceremony', the variable included to measure any consumption shock in the specification, is negative in both regressions, insignificant in the OLS and significant in the 2SLS estimates.

Ration card, which we believe to be an indicator of the availability of legal documentation, significantly increases the usage of electricity. The possession of a ration card enables the holders to access a wide range of publicly provided goods and services from direct energy subsidies to house construction funds etc., ${ }^{13}$ all of which can contribute to improving the living standards of a household.

Households which are primarily engaged in the agricultural activities (i.e. households whose main occupation is agriculture) use around 6.2 per cent less electricity in comparison to the non-agricultural households. As expected, the coefficients of the average age of the household, the size of the household and the ownership of the dwelling where household resides are all positive and significant.

\subsubsection{LPG Access}

Turning next to the LPG case, Table 4 presents three sets of estimates. Columns 1 and 2 present the raw coefficient estimates of probit and IV-probit, respectively, while column $3-$ the column of our main interest - presents estimates in the form of marginal effects of covariates on the event probability (Greene, 1990). ${ }^{14}$ Here the marginal effects are equivalent to examining the partial-derivatives of probability with respect to a covariate while other variables are held constant at their means. The marginal effects in column 3 are from IV-probit estimation.

\footnotetext{
${ }^{13}$ For example, Food Security, Child Development Fund, and Indira Awaas Yojna for construction of houses, among others.

${ }^{14}$ Although the inverse of the standard normal CDF can be seen as Z scores, it is not intuitively obvious to interpret the linear additive effects of covariates on the inverse of the standard normal CDF.
} 
Table 4. LPG access: Results of the regression analysis.

\begin{tabular}{|c|c|c|c|}
\hline Variable & $\begin{array}{c}\text { LPG } \\
\text { (Probit) (1) }\end{array}$ & $\begin{array}{c}\text { LPG } \\
\text { (IV-Probit) (2) }\end{array}$ & $\begin{array}{c}\text { LPG (IV-Probit; } \\
\text { Marginal Effects) (3) }\end{array}$ \\
\hline Scheduled Tribe Households & $\begin{array}{l}-0.360^{n+2+} \\
(-17.78)\end{array}$ & $\begin{array}{l}-0.292^{x+4} \\
(-15.02)\end{array}$ & $\begin{array}{l}-0.091^{* * *} \\
(-17.72)\end{array}$ \\
\hline Scheduled Caste Households & $\begin{array}{l}-0.339^{* * *} \\
(-22.85)\end{array}$ & $\begin{array}{l}-0.244^{* * *} \\
(-16.40)\end{array}$ & $\begin{array}{l}-0.090^{* * * *} \\
(-21.25)\end{array}$ \\
\hline Muslim Households & $\begin{array}{l}-0.113^{* * *} \\
(-6.96)\end{array}$ & $\begin{array}{c}-0.0787^{* * \star} \\
(-5.10)\end{array}$ & $\begin{array}{c}-0.031^{* * *} \\
(-6.71)\end{array}$ \\
\hline Per Capita Consumption Expenditure (MPCE) & $\begin{array}{c}0.00000141^{* * *} \\
(17.15)\end{array}$ & $\begin{array}{c}0.00000345^{* * *} \\
(31.02)\end{array}$ & $\begin{array}{l}0.003^{* * *} \\
(10.38)\end{array}$ \\
\hline Ceremony in the Last 30 Days & $\begin{array}{l}0.0284 \\
(0.70)\end{array}$ & $\begin{array}{l}-0.271^{* * *+} \\
(-5.60)\end{array}$ & $\begin{array}{l}0.008 \\
(0.76)\end{array}$ \\
\hline Ration Card & $\begin{array}{l}0.151^{* * * *} \\
(10.33)\end{array}$ & $\begin{array}{l}0.186^{* * *} \\
(13.19)\end{array}$ & $\begin{array}{l}0.042^{* * *} \\
(10.52)\end{array}$ \\
\hline Household's main Occupation is Agriculture & $\begin{array}{l}-0.383^{* * *} \\
(-26.62)\end{array}$ & $\begin{array}{l}-0.386^{* * * *} \\
(-28.20)\end{array}$ & $\begin{array}{l}-0.113^{4 * *} \\
(-28.25)\end{array}$ \\
\hline Illiterate or informally Educated & $\begin{array}{l}-1.205^{* * *} \\
(-66.34)\end{array}$ & $\begin{array}{l}-0.802^{* * * *} \\
(-29.75)\end{array}$ & $\begin{array}{l}-0.320^{4 * *} \\
(-47.22)\end{array}$ \\
\hline Formal Schooling up to Primary Level & $\begin{array}{l}-0.642^{* * *} \\
(-46.81)\end{array}$ & $\begin{array}{l}-0.359^{* * *} \\
(-18.52)\end{array}$ & $\begin{array}{l}-0.170^{* * * *} \\
(-33.46)\end{array}$ \\
\hline Average Age of the Household & $\begin{array}{l}0.0452^{* * * *} \\
(23.24)\end{array}$ & $\begin{array}{l}0.0304 * \\
(15.07)\end{array}$ & $\begin{array}{l}0.009^{* * *} \\
(15.32)\end{array}$ \\
\hline Square of the Average Age of Household & $\begin{array}{c}-0.000462^{* * *} \\
(-18.60)\end{array}$ & $\begin{array}{c}-0.000341^{* * * *} \\
(-13.61)\end{array}$ & $\begin{array}{c}-0.000096^{* * *} \\
(-13.75)\end{array}$ \\
\hline Total Size of the Household & $\begin{array}{l}0.0503^{* * * *} \\
(18.59)\end{array}$ & $\begin{array}{l}0.0776^{* * *} \\
(27.48)\end{array}$ & $\begin{array}{l}0.0218^{* * * *} \\
(27.04)\end{array}$ \\
\hline Household Owns the Dwelling & $\begin{array}{l}0.117^{*+*} \\
(7.54)\end{array}$ & $\begin{array}{l}0.205^{* * *} \\
(13.16)\end{array}$ & $\begin{array}{l}0.025^{* * *} \\
(5.64)\end{array}$ \\
\hline Household in the rural area & $\begin{array}{l}-0.942^{* * *} \\
(-80.18)\end{array}$ & $\begin{array}{l}-0.777^{* * *} \\
(-49.85)\end{array}$ & $\begin{array}{l}-0.261^{* * *} \\
(-71.90)\end{array}$ \\
\hline Observations & 87753 & 87753 & 87753 \\
\hline
\end{tabular}

Similar to the results in the case of electricity, the coefficients of the scheduled caste and scheduled tribe variables are negative and significant in the LPG case, too. The marginal effects of IV-probit estimates in column 3 show that both the scheduled caste and scheduled tribe status lead to a decrease in event probability (here access to LPG) by almost 0.09 . However, for the Muslim households, the decrease in the event probability is 0.03 .

Of the other variables, the illiterate or informally educated households leads to a decrease of almost 0.32 in the evet probability of accessing LPG. This declines to 0.17 for the households where the head of the household is primary to secondary literate. A household in the rural 
area has 0.26 less probability of accessing LPG compared to those in the urban area. Similarly, households with agriculture as the main occupation leads to a decrease in the probability of accessing LPG by 0.11 . Households with ration card and households who own the dwelling have a higher probability of accessing LPG by 0.042 and 0.025 , respectively. The marginal effect of ceremony is statistically insignificant. Marginal effect of consumption expenditure is quite large: and increase in per capita expenditure by 1 Rupee increases the chances of accessing LPG by $0.003 .{ }^{15}$

\subsection{Predicted values}

Table 5 shows the results of the average predicted outcomes by the categories of determinants in the multivariate regressions. The predicted values are calculated by using IV estimates for both LPG and electricity. The column 2 shows the predicted probabilities of accessing LPG and column 3 shows the predicted outcome of total electricity usage by key variables. Although the IV-probit marginal effects have been discussed above, they do not, of course, explain the average predict probabilities of accessing LPG by social groups. Similarly, while the regression estimates for electricity consumption use natural log of the electricity consumption as a dependent variable, the predicted outcomes have been exponentiated for Table 5.

In the case of LPG, upper caste households have more than 51 per cent chance of accessing LPG. All the three marginalised groups in the sample record average predicted probability less than that of the upper caste households. Of the three marginalised groups, however, it is the scheduled tribe households which have the lowest predicted probability of accessing LPG at around 40 percent. Muslim households have the highest predicted probability in comparison to the scheduled caste and tribe households. Also, the differences between the upper caste and Muslim households are very low in the sample.

There is a large difference in the average predicted probability of rural and urban areas. Keeping other variables constant at their means, the average predicted probability of the rural households is almost half that of the urban households in the sample. Similar large differences in the predicted probabilities can also be seen in the agriculture and education categories in

\footnotetext{
${ }^{15}$ Scaling of this variable by dividing it by 100 (roughly equivalent to \$1.5) shows the high marginal effect of increased income/consumption of a household on the probability of accessing LPG.
} 
the sample. The higher education households have a predicted probability that is more than twice as large as that of the households whose head is illiterate or informally educated.

Table 5. Average Predicted Outcomes

\begin{tabular}{|c|c|c|}
\hline & LPG & Electricity Usage \\
\hline Upper Caste Households & $\begin{array}{c}0.518^{* * *} \\
(0.00259)\end{array}$ & $\begin{array}{l}80.58^{* * *} \\
(0.223)\end{array}$ \\
\hline Scheduled Tribe Households & $\begin{array}{c}0.402^{\star \star \star \prime} \\
(0.00682)\end{array}$ & $\begin{array}{l}72.60^{* * *} \\
(0.535)\end{array}$ \\
\hline Scheduled Caste Households & $\begin{array}{c}0.421^{* \star \star} \\
(0.00526)\end{array}$ & $\begin{array}{l}76.19^{* * *} \\
(0.436)\end{array}$ \\
\hline Muslim Households & $\begin{array}{c}0.486^{\star \star \star} \\
(0.00556)\end{array}$ & $\begin{array}{l}81.04^{* * *} \\
(0.497)\end{array}$ \\
\hline Urban Households & $\begin{array}{c}0.653^{* \star \star} \\
(0.00361)\end{array}$ & $\begin{array}{l}91.34^{* * *} \\
(0.341)\end{array}$ \\
\hline Rural Households & $\begin{array}{c}0.351^{* \star \star \prime} \\
(0.00326)\end{array}$ & $\begin{array}{l}70.21^{* * *} \\
(0.240)\end{array}$ \\
\hline Household does not own the dwelling & $\begin{array}{c}0.419^{\star \star *} \\
(0.00527)\end{array}$ & $\begin{array}{l}60.70^{* * *} \\
(0.405)\end{array}$ \\
\hline Household owns the dwelling & $\begin{array}{c}0.500^{\star * \star} \\
(0.00235)\end{array}$ & $\begin{array}{l}83.55^{* * *} \\
(0.201)\end{array}$ \\
\hline Non-agricultural Households & $\begin{array}{c}0.516^{* * \star} \\
(0.00220)\end{array}$ & $\begin{array}{l}79.98^{* * *} \\
(0.189)\end{array}$ \\
\hline Household's main occupation is agriculture & $\begin{array}{c}0.365^{* * *} \\
(0.00469)\end{array}$ & $\begin{array}{l}75.10^{* * *} \\
(0.382)\end{array}$ \\
\hline Higher Education & $\begin{array}{c}0.627^{* * \star} \\
(0.00601)\end{array}$ & $\begin{array}{l}84.42^{* \star *} \\
(0.551)\end{array}$ \\
\hline Formal Schooling up to Primary Level & $\begin{array}{c}0.486^{* * \star} \\
(0.00280)\end{array}$ & $\begin{array}{l}79.64^{\star \star *} \\
(0.251)\end{array}$ \\
\hline Illiterate or informally Educated & $\begin{array}{c}0.316^{* * \star} \\
(0.00540)\end{array}$ & $\begin{array}{l}71.35^{* * *} \\
(0.391)\end{array}$ \\
\hline Observations $(N)$ & 87753 & 87753 \\
\hline
\end{tabular}

Standard errors in parentheses:

probabilities of access to LPG; electricity usage is exponentiated from natural log to $\mathrm{KWh}$

$p<0.05,{ }^{* *} p<0.01,{ }^{* * *} p<0.001$

Average of the outcomes; other variables are at their means.

As in the case of LPG, in the case of electricity usage, too, the scheduled tribe households have the lowest predicted outcome followed by the scheduled caste households. The Muslim households, however, have a predicted outcome that is larger than that of all the other social groups, including the upper caste households. This should not be surprising due to the relatively higher concentration of Muslim households in the urban areas. Similar to the LPG case, the households in the urban areas, on average, get better access to the electricity consumption in the sample. The predicted probability of electricity usage increases as we move up from the 'illiterate or informally educated' to the 'highly-educated' category households. The agriculture and non-agriculture divide is again significant in the predicted outcomes (in line, one may say, with the supply side issues that are involved in providing electricity in the rural areas). Finally, it may be noted that the differences in predicted 
outcomes by our categories in electricity consumption are lower than those for the LPG access.

\subsection{Estimating Discrimination}

In large parts of India, members of the scheduled caste and scheduled tribe communities are often denied access, through several discriminatory measures, to common public facilities. Members of the scheduled tribes mostly live in the relatively remote areas. Muslim households are largely concentrated in the ghettos, while the members of the scheduled caste communities often live in segregated hamlets and blocks. In this sub-section, we present estimates of the share of unobservable factors in predicting the differences in averages of probability of accessing LPG and electricity usage by the three marginalised groups in the sample. In the light of our regression estimates and predicted values, it is clear that the estimates of discrimination are likely to be more relevant for the scheduled tribe and scheduled caste than for the Muslim households in the sample.

The pair wise decomposition methodology of regression estimates was first proposed by Oaxaca, 1973 and Blinder, 1973. This methodology is primarily for the linear models and the estimation of decomposition methods were primarily used for the linear decomposition (Neumark, 1988; Oaxaca, 1973; Oaxaca and Ransom, 1994). However, access to LPG is a binary dependent variable in this paper and IV-probit estimation has been employed. For the decomposition of the nonlinear models with unobservable dependent variable, several methods have emerged on the basis of Oaxaca-Blinder methodology in the literature (Bauer and Sinning, 2008; Fairlie, 2005; Gomulka and Stern, 1990; Yun, 2004). We employ the methodology proposed by (Yun, 2004). Due to the endogeneity bias in OLS and Probit estimates, Oaxaca-Blinder decomposition in the analysis uses the consistent estimates of 2SLS and IV-probit regression. ${ }^{16}$

\footnotetext{
${ }^{16}$ It is equally important to mention that Oaxaca-Blinder method uses linear predictions from the regression estimations. Therefore, for electricity, the group differences in predicted outcomes are in log functional form from $2 \mathrm{SLS}$ and, for LPG, area under the z-score of a normal distribution for IV-probit estimates. It is, therefore, obvious that the predicted outcomes of social groups are functionally different from the predicted outcomes in Table 5, where exponentiated and probability values have been presented post estimation. Also, in Table 5, the predicted outcomes have been calculated by keeping other variables at their means and, of course, this is not the case with decomposition analysis. In estimating discrimination, this should not be considered as a major limitation, as our main interest is in the proportion of unexplained to explained part in predicting group based differences.
} 
Tables 6 and 7 show the decomposition of total differences in predictions due to the characteristics and unexplained part for the scheduled caste, scheduled tribe and Muslim households in the sample. ${ }^{17}$ We are mainly interested in the proportion of unobservable factors (differences in returns to the determinants of energy goods) and their statistical significance in the sample. ${ }^{18}$

Table 6. Decomposition for LPG

\begin{tabular}{|c|c|c|c|}
\hline & Scheduled Tribe & Scheduled Caste & Muslim \\
\hline Total difference & $\begin{array}{c}0.162^{* * \star} \\
(0.00493)\end{array}$ & $\begin{array}{c}0.213^{* * *} \\
(0.00468)\end{array}$ & $\begin{array}{c}0.105^{\star \star \star} \\
(0.00527)\end{array}$ \\
\hline Explained Difference & $\begin{array}{c}0.0709^{\star * \star} \\
(0.00408)\end{array}$ & $\begin{array}{c}0.0986^{* \star *} \\
(0.00281)\end{array}$ & $\begin{array}{c}0.0582^{\star \star *} \\
(0.00348)\end{array}$ \\
\hline Unexplained Difference & $\begin{array}{c}0.0907^{\star \star \star} \\
(0.00491)\end{array}$ & $\begin{array}{c}0.115^{\star \star \star} \\
(0.00426)\end{array}$ & $\begin{array}{c}0.0463^{\star \star \star} \\
(0.00517)\end{array}$ \\
\hline
\end{tabular}

\begin{tabular}{llll}
\hline U/E Ratio & 1.2792 & 1.1663 & 0.7955 \\
\hline Standard errors in parentheses & & &
\end{tabular}

${ }^{*} p<0.05,{ }^{* *} p<0.01,{ }^{* * *} p<0.001$

Table 7. Decomposition for Electricity

\begin{tabular}{|c|c|c|c|}
\hline & Scheduled Tribe & Scheduled Caste & Muslim \\
\hline Total difference & $\begin{array}{c}0.350^{* * \star} \\
(0.00792)\end{array}$ & $\begin{array}{c}0.234^{* * *} \\
(0.00835)\end{array}$ & $\begin{array}{c}0.0477^{\star * \star} \\
(0.00854)\end{array}$ \\
\hline Explained Difference & $\begin{array}{c}0.205^{\star \star \star} \\
(0.00704)\end{array}$ & $\begin{array}{c}0.0980^{* * *} \\
(0.00474)\end{array}$ & $\begin{array}{c}0.0294^{\star * *} \\
(0.00588)\end{array}$ \\
\hline Unexplained Difference & $\begin{array}{c}0.146^{\star \star \star} \\
(0.00839)\end{array}$ & $\begin{array}{c}0.136^{\star * \star} \\
(0.00738)\end{array}$ & $\begin{array}{c}0.0183^{*} \\
(0.00782)\end{array}$ \\
\hline U/E Ratio & 0.7121 & 1.3877 & 0.6224 \\
\hline
\end{tabular}

Standard errors in parentheses

${ }^{\star} p<0.05,{ }^{* *} p<0.01,{ }^{* * *} p<0.001$

Columns 2,3 , and 4 in the tables present the decomposition estimates of the three marginalised social groups, respectively. Total difference, difference by endowments (characteristics), and difference by the unobservable factors are presented in second, third, and fourth row respectively. ${ }^{19}$ In the last row we have constructed the ratio of unexplained

\footnotetext{
17 For pairwise decomposition of differences in mean outcomes we have only presented the two-fold decomposition. We consider the intersection of characteristics' differences with low returns (coefficients) are a part of discrimination against marginalised social groups.

${ }^{18}$ We have reported the estimates of total unobservable factors (differences in coefficients - slopes and intercepts). However, detailed decomposition of all the determinants can be presented.

${ }^{19}$ It is important to mention that the decomposition estimates are likely to depend on the choice of base category among dummy covariates. However, we have employed the proposed transformations in the literature by which the results of the decomposition are independent of the choice of the omitted category (Jann, 2008; Yun, 2005).
} 
share in the total difference to the explained share in the difference (U/E). This ratio can vary from zero to infinity, assuming there exists total differences in the group outcomes. The larger the value of this ratio, the more is the proportion of latent factors in determining the total differences for the particular social group against the upper caste households. ${ }^{20}$ This unexplained to explain ratio can be seen as a simple rule to construct an easily understandable comparison between the marginalised groups.

The estimates in Table 6 show that all the three marginalised groups have significant share of the unexplained part in determining the predicted outcomes vis-à-vis the upper caste households in the sample. For the Muslim households, besides the minimum total differences, the unexplained to explained ratios is minimum in comparison to the scheduled caste and scheduled tribe households.

Of the decomposition for electricity in Table 7, while the scheduled caste and scheduled tribe households have significant proportion of unexplained part and record higher unexplained to explained ratio in comparison to the Muslim households, the coefficient of the Muslim households for the unexplained part is very low with very low difference in the predicted outcomes. If these unexplained factors are termed as discrimination in the supply of energy services, then, among the major social groups, it is the scheduled caste and scheduled tribe households who suffer most discrimination (unequal returns) in the equality spaces of electricity and LPG distribution.

\section{Conclusion and Policy Implications}

This paper has studied the determinants of access to LPG and electricity usage by households in India. Our sample consists of 87753 households. In contrast to the previous studies, the analysis of the paper covers all the states and union territories in India and includes both the rural and urban areas.

The results show that higher income and higher education levels are both associated with an increased probability of accessing LPG and higher usage of electricity. Households in the rural

\footnotetext{
${ }^{20}$ Although decomposition can be formulated from the viewpoint of any of the two groups in the equation, we have used the viewpoint of marginalised groups in all three pairwise decompositions. However, results on the reversed viewpoints can easily be produced.
} 
areas, as expected, face severe supply constraints in comparison to the urban households and their probability of accessing LPG and electricity usage is significantly lower.

The major findings of the paper, however, relate to the lower predicted probabilities of accessing LPG by the households belonging to all the three marginalised social groups and the lower predicted outcomes of electricity usage by two of the three marginalised social groups, viz., the scheduled caste and scheduled tribe. We carried out a decomposition analysis to explore the role of what we have called the systematic discrimination against the marginalised social groups. We found that the contribution of the unequal treatment in their lower predicted probabilities of accessing LPG and lower predicted outcome in electricity usage is the largest for the scheduled caste households. As already mentioned, the members of the scheduled castes, the scheduled tribes, and the Muslims communities mainly reside either in the isolated hamlets or in remote areas or urban ghettos due to social isolation and other structural factors, and these make it possible to discriminate against them in the supply of energy goods (Kemmler, 2007).

At the policy level, there are a number of large scale interventions and policies by the government to overcome inequalities and poverty in general, but very few for dealing with the issue of accessing cleaner energy sources by socially marginalised groups in India. Rajiv Gandhi Grameen Vidutikaran Yojna - which aims to provide free electricity connection to below poverty line households - only targets the rural areas. Some state governments also try to implement the policy of limited free electricity to scheduled households; this, however, remains mostly ineffective due to the poor supply quality (Singh, 2003, p. 136). Although there are recent amendments and extensions in the policies through Decentralised Distributed Generation, Deendayal Upadhyaya Gram Jyoti Yojna, and Integrated Power Development Scheme to strengthen the sub-transmission in both rural and urban areas and to classify agricultural activities and household consumers separately in the rural areas, the results of these policies on the weaker sections of the societies are yet to be felt.

Equally, while subsidy is provided for the LPG cylinders, the administration rarely monitors the distribution of these cylinders carefully. Similar to the schemes in extending electricity usage, PAHAL (Direct Benefit Transfer for LPG) has been launched to reduce the leakages in the LPG subsidies. However, the past experience suggests that this is likely to benefit mainly the non-poor sections of the society (Pachauri and Spreng, 2004), as the supply infrastructure 
of LPG to the socially marginalised households remains a major constraint. Our analysis suggests that the policy makers also need to address the issues arising from the socioeconomic bias against the marginalised groups in a predominantly supply driven market. ${ }^{21}$

Since 2015 the national government is pursuing a market based pricing policy and elimination of subsidy on LPG. These follows the Rangarajan (2012) Committee Report which proposed that the quantity and prices of natural gas should not be under the control of the government, but instead be controlled by the market forces. However, LPG continues to be subsidised (Sen, 2015) for household consumption, though this subsidy is now kept at approximately 186 kilograms LPG per year. It is too early to say what the measure impacts of these major reforms in the pricing of natural gas are likely to be, though our belief is that the disadvantages faces by the SC and ST in accessing energy goods are unlikely to be remedied by these changes.

Finally, it is worth noting that while in the provision of employment and education, the government, through its reservation quotas and other affirmative actions, has undoubtedly improved the position of many members of the scheduled caste and scheduled tribe communities, the outcome would appear to have been much less sanguine in the provision of energy goods. The targeted policies here would appear to have had only limited impacts. There is a dichotomy here and the relevant government agencies clearly need to reflect on why this has been so and consider whether they are ending up, willy-nilly, discriminating against the marginalised groups in the provision of energy goods.

\footnotetext{
${ }^{21}$ Any policy intervention to improve the access to modern energy goods by the marginalised groups should clearly be based on an awareness of the fact that most households belonging to the marginalised groups, as we have already noted in the text, reside either in isolated hamlets (in the case of SC households in rural areas) or in remote areas (in the case of ST households) or in urban ghettos (in the case of Muslim households). These areas can be specifically targeted with well-focused policies (including improving the supply infrastructure).
} 


\section{References}

Ahn S-J, Graczyk D. Understanding energy challenges in India: Policies, players and issues. Paris: 2012. doi:10.1109/MIAS.2010.939812.

Alam M, Sathaye J, Barnes D. Urban household energy use in India : Efficiency and policy implications. Energy Policy 1998;26:885-91. doi:10.1016/S0301-4215(98)00008-1.

Bauer TK, Sinning M. An extension of the Blinder-Oaxaca decomposition to nonlinear models. Adv Stat Anal 2008;92:197-206. doi:10.1007/s10182-008-0056-3.

Behm H. Socio-economic determinants of mortality in Latin America. Popul Bull 1980;13:1-15.

Benzeval M, Taylor J, Judge K. Evidence on the Relationship between Low Income and Poor Health: Is the Government Doing Enough? Fisc Stud 2000;21:375-99. doi:10.1111/j.1475-5890.2000.tb00029.x.

Besley T, Burgess R. Land Reform , Poverty Reduction , and Growth : Evidence from India. Q J Econ 2000;115:389-430.

Bhattacharyya SC. Energy access problem of the poor in India: Is rural electrification a remedy? Energy Policy 2006;34:3387-97. doi:10.1016/j.enpol.2005.08.026.

Blinder AS. Wage Discrimination: Reduced Form and Structural Estimates. J Hum Resour 1973;8:436. doi:10.2307/144855

Blundell R, Preston IAN. Income , Expenditure and the Living Standards of UK Households. Fisc Stud 1995;16:40-54.

Cameron AC, Trivedi PK. Microeconometrics Using Stata, Revised Edition, Stata Press; 2010, p. 706.

Census of India. Houselisting and Housing Census Data Highlights - 2011. 2011.

Chaurey A, Ranganathan M, Mohanty P. Electricity access for geographically disadvantaged rural communitiestechnology and policy insights. Energy Policy 2004;32:1693-705. doi:10.1016/S0301-4215(03)00160-5.

D'Sa A, Murthy KVN. LPG as a cooking fuel option for India. Energy Sustain Dev 2004;8:91-106. doi:10.1016/S0973-0826(08)60471-8.

Danh VT, Khai HV. Household demand and supply for clean groundwater in the Mekong Delta, Vietnam. Renewables Wind Water, Sol 2015;2. doi:10.1186/s40807-014-0004-7.

David A. Freedman, Jasjeet S. Sekhon. Endogeneity in Probit Response Models. Polit Anal 2010;18:138-50. doi:https://doi.org/10.1093/pan/mpp037.

Davidson J. Econometric theory. Blackwell Publishers; 2000.

Deaton A. Inequalities in Income and Inequalities in Health. Cambridge, MA: 1999. doi:10.3386/w7141.

Ellegard A. Cooking Fuel Smoke and Respiratory Symptoms among Women in Low-Income Areas in Maputo. Environ Health Perspect 1996;104:980-5. doi:10.2307/3433146.

Ellegard A, Egneus H. Urban energy: Exposure to biomass fuel pollution in Lusaka. Energy Policy 1993;21:61522. doi:10.1016/0301-4215(93)90044-G.

Fairlie RW. An extension of the Blinder-Oaxaca decomposition technique to logit and probit models. J Econ Soc Meas 2005;30:305-16. doi:http://iospress.metapress.com/content/0747-9662/.

Fullerton DG, Bruce N, Gordon SB. Indoor air pollution from biomass fuel smoke is a major health concern in the developing world. Trans R Soc Trop Med Hyg 2008;102:843-51. doi:10.1016/j.trstmh.2008.05.028.

Gayer L, Jaffrelot C. Muslims in Indian Cities: Trajectories of Marginalisation. London: Hurst \& Company; 2012.

Golshan M, Faghihi M, Marandi MM. Indoor women jobs and pulmonary risks in rural areas of Isfahan, Iran, 2000. Respir Med 2002;96:382-8. doi:10.1053/rmed.2002.1288.

Gomulka J, Stern N. The Employment of Married Women in the United Kingdom 1970-83. Economica 1990;57:171-99. doi:10.2307/2554159.

Government of India. Energy Sources of Indian Households for Cooking and Lighting. 2012.

Greene WH. Econometric analysis. New York: Macmillan; 1990.

Gupta G, Köhlin G. Preferences for domestic fuel: Analysis with socio-economic factors and rankings in Kolkata, 
India. Ecol Econ 2006;57:107-21. doi:10.1016/j.ecolecon.2005.03.010.

Heckman JJ. Sample Selection Bias as a Specification Error. Econometrica 1979;47:153. doi:10.2307/1912352.

Heltberg R. Fuel switching: Evidence from eight developing countries. Energy Econ 2004;26:869-87.

doi:10.1016/j.eneco.2004.04.018.

Hendrickx J. The Stata Journal. Stata J 2002;2:103-5.

IEA. The World Energy Outlook (WEO). Paris: 2002.

Jann B. The Blinder-Oaxaca decomposition for linear regression models. Stata J 2008;8:453-79.

Jones CA, Milkove D, Paszkiewicz L. Farm household well-being: Comparing consumption and income based measures. 2010.

Kanagawa M, Nakata T. Assessment of access to electricity and the socio-economic impacts in rural areas of developing countries. Energy Policy 2008;36:2016-29. doi:10.1016/j.enpol.2008.01.041.

Kemmler A. Factors influencing household access to electricity in India. Energy Sustain Dev 2007;11:13-20. doi:10.1016/S0973-0826(08)60405-6.

Khandker, Shahidur R.; Barnes, Douglas F.; Samad H. Energy poverty in rural and urban India: are the energy poor also income poor? 2010.

Kumar A, Manna GC, Chitkara S, Rathore GS, Kumar S. Energy Statistics. New Delhi: 2012.

Lam NL, Smith KR, Gauthier A, Bates MN. Kerosene : a Review of Household Uses and Their Hazards in Lowand Middle-Income Countries. J Toxicol Environ Heal Part B Crit Rev 2012;15:396-432. doi:10.1080/10937404.2012.710134.

Liao TF. Interpreting Probability Models: Logit, Probit, and Other Generalized Linear Models. London: SAGE Publications; 1994.

Long JS, Freese J. Regression Models for Categorical Dependent Variables using Stata. Stata Press; 2001.

Magri S. Italian households' debt: The participation to the debt market and the size of the loan. Empir Econ 2007;33:401-26. doi:10.1007/s00181-006-0107-0.

Meier H, Rehdanz K. Determinants of residential space heating expenditures in Great Britain. Energy Econ 2010;32:949-59. doi:10.1016/j.eneco.2009.11.008.

Meyer BD, Sullivan JX. Viewpoint: Further results on measuring the well-being of the poor using income and consumption. Can J Econ 2011;44:52-87. doi:10.1111/j.1540-5982.2010.01623.x.

Meyer BD, Sullivan JX. Changes in the consumption, income, and well-being of single mother headed families. Am Econ Rev 2008;98:2221-41. doi:10.1257/aer.98.5.2221.

Meyer BD, Sullivan JX. Measuring the Well-Being of the Poor Using Income and Consumption. J Hum Resour 2003;38:1180-220. doi:10.2307/3558985.

Mishra VK, Retherford RD, Smith KR. Cooking with biomass fuels increases the risk of tuberculosis. Natl Fam Health Surv Bull 1999:1-4.

Modi V. Improving Electricity Services in Rural India: An initial assessment of recent initiatives and some recommendations. 2005.

Neumark D. Employers' Discriminatory Behavior and the Estimation of Wage Discrimination. J Hum Resour 1988;23:279-95. doi:10.2307/145830.

Newey WK. Efficient estimation of limited dependent variable models with endogenous explanatory variables. J Econom 1987;36:231-50. doi:10.1016/0304-4076(87)90001-7.

Oaxaca R. Male-Female Wage Differentials in Urban Labor Markets. Int Econ Rev (Philadelphia) 1973;14:693709. doi:10.2307/2525981.

Oaxaca RL, Ransom MR. Journal of econometrics. vol. 61. Elsevier; 1994.

Oda H, Tsujita Y. The determinants of rural electrification: The case of Bihar, India. Energy Policy 2011;39:3086 95. doi:10.1016/j.enpol.2011.02.014.

Pachauri S, Spreng D. Measuring and monitoring energy poverty. Energy Policy 2011;39:7497-504.

doi:10.1016/j.enpol.2011.07.008. 
Pachauri S, Spreng D. Energy Use and Energy Access in Relation to Poverty. Econ Polit Wkly 2004;39:271-8.

Poterba JM. Lifetime Incidence and the Distributional Burden of Excise Taxes. Am Econ Rev 1989;79:325-30.

Raha D, Mahanta P, Clarke ML. The implementation of decentralised biogas plants in Assam, NE India: The impact and effectiveness of the National Biogas and Manure Management Programme. Energy Policy 2014;68:80-91. doi:10.1016/j.enpol.2013.12.048.

Rangarajan C. Report of the Committee On the Production Sharing Contract Mechanism in Petroleum Industry. 2012.

Rao MN, Reddy BS. Variations in energy use by Indian households: An analysis of micro level data. Energy 2007;32:143-53. doi:10.1016/j.energy.2006.03.012.

Rao ND. Does (better) electricity supply increase household enterprise income in India? Energy Policy 2013;57:532-41. doi:10.1016/j.enpol.2013.02.025.

Sargan JD. The Estimation of Economic Relationships using Instrumental Variables. Econometrica 1958;26:393. doi:10.2307/1907619.

Sen A. Gas Pricing Reform in India : Implications for the Indian gas landscape. 2015.

Singh RB. Scheduled Caste Welfare: Myth or Reality. New Delhi: APH Publishing Corporation; 2003.

Slesnick DT. Gaining Ground: Poverty in the Postwar United States. J Polit Econ 1993;101:1-38.

Smith KR. Health, energy, and greenhouse-gas impacts of biomass combustion in household stoves. Energy Sustain Dev 1994;1:23-9. doi:10.1016/S0973-0826(08)60067-8.

Smith KR. Fuel Combustion, Air Pollution Exposure, and Health: The Situation in Developing Countries. Annu Rev Energy Environ 1993;18:529-66. doi:10.1146/annurev.eg.18.110193.002525.

Stock JH, Wright JH, Yogo M. A Survey of Weak Instruments and Weak Identification in Generalized Method of Moments. J Bus Econ Stat 2002;20:518-29. doi:10.2307/1392421.

Thorat S. Dalits in India: Search for a Common Destiny. New Delhi: SAGE Publications; 2009.

WEC. Pricing Energy in Developing Countries. London: 2001.

WEO. World Energy Outlook. WEO Energy Access Database 2014.

http://www.worldenergyoutlook.org/resources/energydevelopment/energyaccessdatabase/.

World Bank. India: Access of the poor to clean household fuels. Washington, DC: 2003.

Yun M-S. A SIMPLE SOLUTION TO THE IDENTIFICATION PROBLEM IN DETAILED WAGE

DECOMPOSITIONS. Econ Inq 2005;43:766-72. doi:10.1093/ei/cbi053.

Yun M-S. Decomposing differences in the first moment. Econ Lett 2004;82:275-80.

doi:10.1016/j.econlet.2003.09.008.

Zhang J, Smith KR. Household air pollution from coal and biomass fuels in China: Measurements, health impacts, and interventions. Environ Health Perspect 2007;115:848-55. doi:10.1289/ehp.9479. 